\title{
Impact of Phytophthora agathidicida infection on canopy and forest floor nutrient concentrations and fluxes in a kauri-dominated forest
}

\author{
Luitgard Schwendenmann $^{1}$ and Beate Michalzik ${ }^{2}$ \\ ${ }^{1}$ The University of Auckland \\ ${ }^{2}$ Friedrich-Schiller-Universitat Jena
}

December 11, 2020

\begin{abstract}
Kauri dieback, caused by Phytophthora agathidicida, is an ecosystem disturbance that poses a recent threat to the survival of kauri (Agathis australis) forests in New Zealand. Throughfall and stemflow play an important role in meeting the nutrient requirements of kauri forests. However, the effects of kauri dieback on canopy nutrient deposition remain unknown. Here we measured throughfall, stemflow and forest floor water yield and nutrient concentrations and fluxes (potassium, calcium, magnesium, manganese, silicon, sulphur, sodium, iron) of ten kauri trees differing in soil P. agathidicida DNA concentration and health status. We did not observe an effect of soil $P$. agathidicida DNA concentration on throughfall and stemflow water yield. Throughfall and forest floor nutrient concentrations and fluxes tended to decrease (up to $50 \%$ ) with increasing soil $P$. agathidicida DNA concentration. Significant effects were found for potassium and manganese fluxes in throughfall, and calcium and silicon fluxes in forest floor leachate. The decline in nutrient input will have implications on plant nutrition, tree health and susceptibility to future pathogen infection in these ecologically unique kauri forests. Given our findings and the increasing spread of Phytophthora species worldwide, research on the underlying physiological mechanisms linking dieback and plant-soil nutrient fluxes is critical.
\end{abstract}

\section{Hosted file}

Schwendenmann and Michalzik_manuscript plus tables.pdf available at https://authorea.com/ users/382378/articles/498284-impact-of-phytophthora-agathidicida-infection-on-canopyand-forest-floor-nutrient-concentrations-and-fluxes-in-a-kauri-dominated-forest

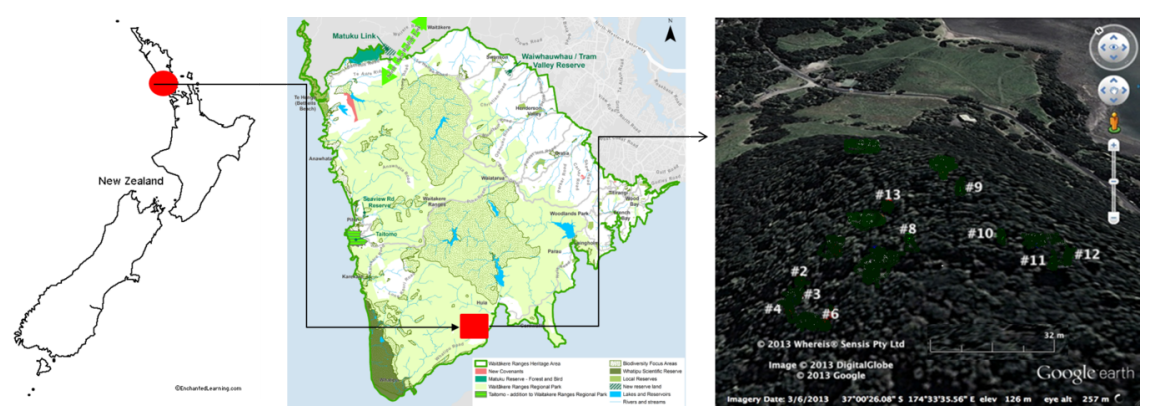



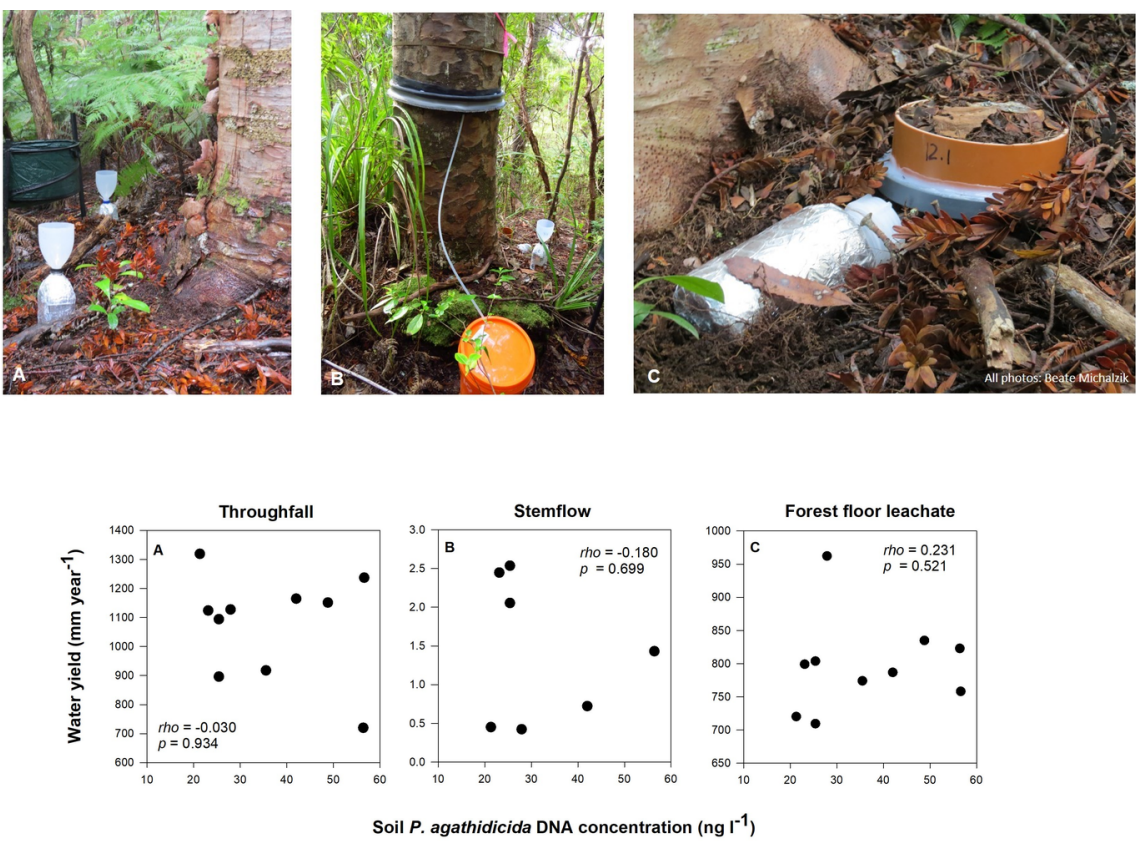

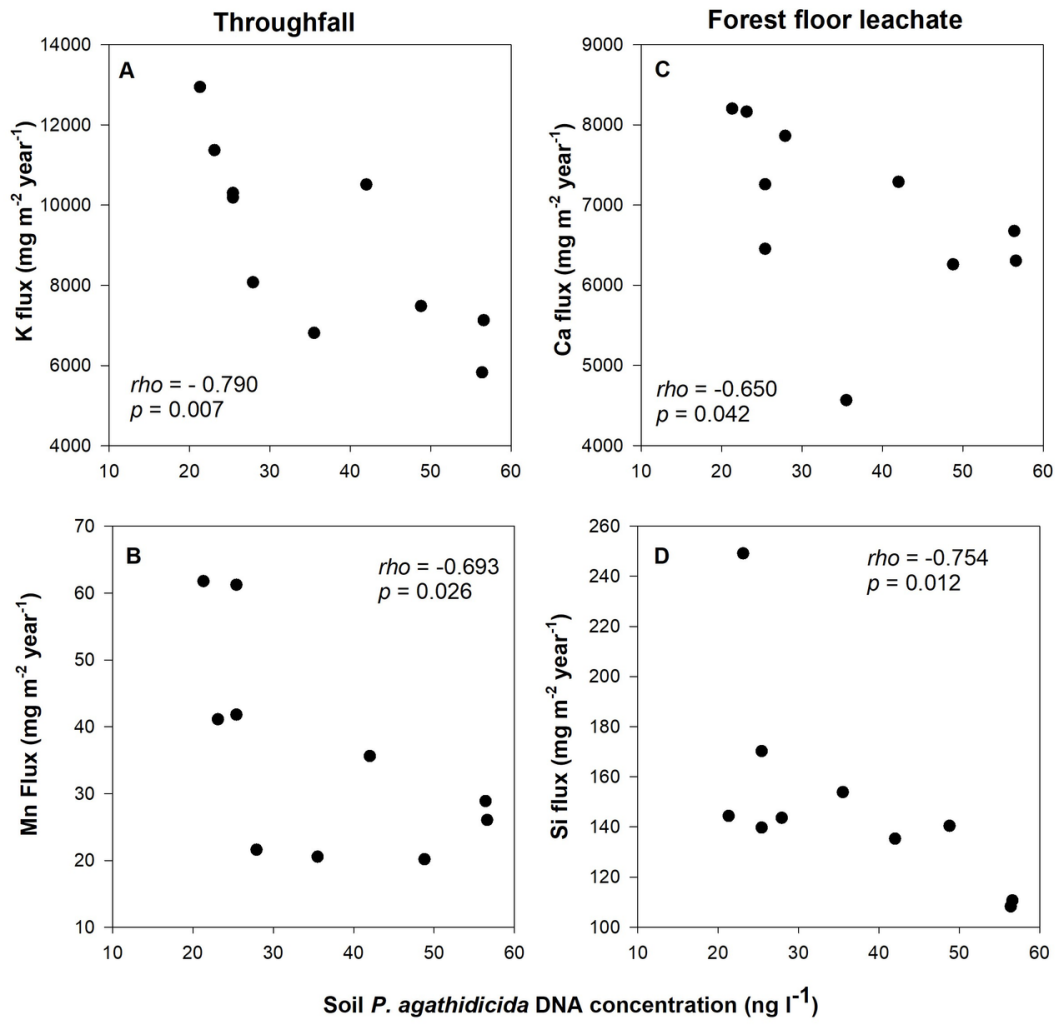
Soil P. agathidicida DNA concentration

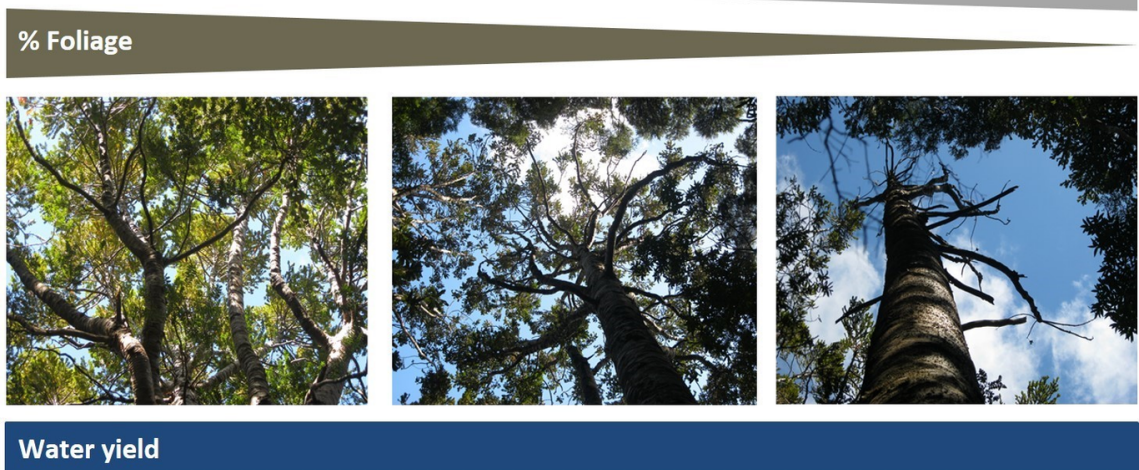

Nutrient fluxes 